Full-text Available Online at https://www.ajol.info/index.php/jasem http://ww.bioline.org.br/ja
J. Appl. Sci. Environ. Manage.

Vol. 22 (11) 1807-1816 November 2018

\title{
Arsenic occurrence in Malawi groundwater
}

\section{${ }^{* 1}$ RIVETT, MO; ${ }^{1}$ ROBINSON, HL; ${ }^{1}$ WILD, LM; ${ }^{1}$ MELVILLE, J; ${ }^{1}$ MCGRATH, L; ${ }^{2}$ PHIRI, P; ${ }^{1}$ FLINK, J; ${ }^{3}$ WANANGWA, GJ $;{ }^{2}$ MLETA, P; ${ }^{1}$ MACLEOD, SSP; ${ }^{1}$ MILLER, AVM; ${ }^{1}$ KALIN, RM}

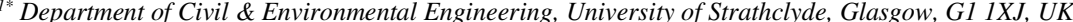 \\ ${ }^{2}$ Ministry of Agriculture, Irrigation and Water Development, Tikwere House, Private Bag 390, Lilongwe 3, Malawi \\ ${ }^{3}$ Ministry of Agriculture, Irrigation and Water Development, Regional Irrigation and Water Development Office - South, Private Bag 13, \\ Blantyre, Malawi \\ *Corresponding author's Email: Michael.Rivett@strath.ac.uk
}

\begin{abstract}
Despite an estimated 90,000 groundwater points, mostly hand-pumped boreholes, being used for drinking-water supply in Malawi, evaluation of groundwater arsenic has been limited. Here we review the literature and collate archive data on groundwater arsenic occurrence in Malawi; add to these data, by surveying occurrence in handpumped boreholes in susceptible aquifers; and, conclude on risks to water supply. Published literature is sparse with two of the three studies reporting arsenic data in passing, with concentrations below detection limits. The third study of 25 alluvial aquifer boreholes found arsenic mostly at $1-10 \mu \mathrm{g} / \mathrm{l}$ concentration, but with four sites above the World Health Organisation (WHO) $10 \mu \mathrm{g} / \mathrm{l}$ drinking-water guideline, up to $15 \mu \mathrm{g} / \mathrm{l}$; the study also discerned hydrochemical controls. Archive data from non-governmental organisation (NGO) borehole testing (two datasets) exhibited below detection results. Our surveys in 2014-18 of hand-pumped supplies in alluvial and bedrock aquifers tested 310 groundwater sites (78\% alluvial, $22 \%$ bedrock) and found below test-kit detection $(<10 \mu \mathrm{g} / \mathrm{l})$ arsenic throughout, except possible traces at two boreholes containing geothermal-groundwater contributions. Our subsequent survey of 15 geothermal groundwater boreholes/springs found four sites with arsenic detected at 4-12 $\mu \mathrm{g} / \mathrm{l}$ concentration. These sites displayed the highest temperatures, supporting increased arsenic being related to a geothermal groundwater influence. Our 919 sample datase overall indicates arsenic in Malawian groundwater appears low, and well within Malawi's drinking-water standard of 50 $\mu \mathrm{g} / \mathrm{l}$ (MS733:2005). Still, however, troublesome concentrations above the WHO drinking-water guideline occur. Continued research is needed to confirm that human-health risks are low; including, increased monitoring of the great many hand-pumped supplies, and assessing hydro-biogeochemical controls on the higher arsenic concentrations found.
\end{abstract}

\section{DOI: https://dx.doi.org/10.4314/jasem.v22i11.16}

Copyright: Copyright (C) 2018 Rivett et al. This is an open access article distributed under the Creative Commons Attribution License (CCL), which permits unrestricted use, distribution, and reproduction in any medium, provided the original work is properly cited.

Dates: Received: 13 November 2018; Revised: 26 November 2018; Accepted 30 November 2018

Keywords: Arsenic; Groundwater quality; Malawi; Drinking water

Arsenic in groundwater is a global concern due to its potential to impact human-health when contaminated groundwater is used for drinking-water supply. Cases of widespread contamination have emerged in South/North America, Europe, South-East Asia, and Bangladesh-India where 40 million people were affected (Ahmed et al., 2004; Smedley and Kinniburgh, 2013). Exposure in water is generally due to toxic trivalent arsenite As (III) and has been linked to skin, bladder and lung cancers, skin legions, cardiovascular disease and infant development (George et al., 2012). European and US regulations implement standards equivalent to the WHO drinkingwater guideline, $10 \mu \mathrm{g} / \mathrm{l}$ (WHO, 2011). However, many developing nations still adopt the pre-1993 WHO drinking-water guideline of $50 \mu \mathrm{g} / \mathrm{l}$, including Malawi (Malawi Standards (2005) for waters delivered from boreholes and protected shallow wells). This may be due to a lack of analytical facilities to test for low concentrations, or compliance issues with realistically meeting lower standards (Smedley and Kinniburgh, 2013). Arsenic is, however, now designated a global level priority chemical to monitor in assessing performance against the Sustainable Development Goal (SDG) target 6.1 indicator of population proportion using safely managed drinking water (WHO and UNICEF, 2017).

Widespread groundwater contamination usually arises from desorption/dissolution of host rock arsenic naturally present. Concentrations range from $<0.5$ to $15,000 \mu \mathrm{g} / \mathrm{l}$ depending upon the mineralogy and fluidrock interaction occurring. Elevated concentrations, above $10 \mu \mathrm{g} / \mathrm{l}$, are the exception rather than rule (Smedley and Kinniburgh, 2013). Many minerals contain arsenic with sulphide minerals such as arsenian pyrite $\left(\mathrm{Fe}(\mathrm{SAs})_{2}\right)$ and arsenopyrites (FeAsS) forming key geogenic sources. Although solid-phase

*Corresponding author's Email: Michael.Rivett@strath.ac.uk 
arsenic contents influence groundwater contamination, aquifer material in some of the most prominent cases may not be that high in arsenic, possibly containing from as low as 1-20 mg/kg (Smedley and Kinniburgh, 2002). Solution conditions favouring arsenic release are hence often key with a complex range of possible biogeochemical reactions influencing release (Hoque et al., 2017). Generalising though, mobilisation of rock-formation arsenic into groundwater is most favourable under oxidising conditions at high $\mathrm{pH}$, or else, perhaps more commonly, strongly reducing conditions (Smedley and Kinniburgh, 2013). For instance, dissolution of arsenic bearing iron-oxides may occur upon reducing conditions where the presence (and lability) of organic matter and sulfates are important. Reduction of the latter to sulfide may remove arsenic from solution due to insoluble arsenic sulfide formation, or else sorption to iron sulfides (Rowland et al., 2011).

Groundwater arsenic assessment at national levels is not always comprehensive. It could be perceived an unlikely issue in the prevalent rock types, a country may have insufficient analytical resources, or there is an absence of obvious health impacts - a potential false security. The global case map of Smedley and Kinniburgh (2013) does not identify any African arsenic-affected aquifers, with only four instances of (mining related) occurrence. This may arise from African hydrochemical conditions being less prone, however, monitoring may often be inadequate (Ravenscroft et al., 2009). The recent review of arsenic in African waters by Ahoulé et al. (2015) echoes and exemplifies, in detail, confirming there appears limited assessment of arsenic in Malawi (Ahoule et al., 2015). The British Geological Survey (BGS) (having longterm hydrogeological experience in Malawi and significant arsenic experience globally (Smedley and Kinniburgh, 2013)) in 2004 anticipated arsenic in Malawi's main aquifers to be low: below $50 \mu \mathrm{g} / \mathrm{l}$ and possibly $10 \mu \mathrm{g} / \mathrm{l}$, in most groundwater from the Basement rock and Mesozoic (Karoo and Cretaceous) sediments (BGS, 2004). They caution, however, this anticipation required assessment, in conjunction with testing of alluvial aquifer where concentrations may be locally higher. Mapoma and Xie (2014) likewise perceive arsenic problems to be low, albeit still based upon sparse data. Our study hence aims to: review the available literature and assemble archive data on groundwater arsenic occurrence in Malawi; add to this knowledge base, by surveying occurrence in drinkingwater supply boreholes in susceptible aquifer types; and, conclude upon the current understanding of risks posed to Malawi's drinking-water supply and its future needs.

\section{MATERIALS AND METHODS}

Description of study area: Malawi is a low-income country in Southern Africa. Rural communities account for around $85 \%$ of its $>17$ million population who largely depend upon groundwater. Access to groundwater continues to increase with hand-pumped borehole community supply 'water-points' pivotal to Water and Sanitation Hygiene (WaSH) programmes and SDG 6 attainment. Water-point mapping under our Climate Justice Fund: Water Futures Programme (CJF) (www.cjfwaterfuturesprogramme.com) has so far mapped 61,000 water points, and it is projected around 90,000 points may exist across Malawi.

Malawi is positioned on an elongate plateau towards the southern extreme of the western branch of the EastAfrican Rift System (EARS). Its Miocene-recent structural geology (Fig. 1a) is mainly influenced by the EARS and bound by many faults. Ground elevations decline from $3000 \mathrm{~m}$ in the highlands to $30 \mathrm{~m}$ in the southern valley plains around the Shire River, the sole outflow from Lake Malawi. The deeper geology is largely influenced by the basement-forming PreCambrian metamorphic lithologies arising from events associated with the formation of the Cape Fold Belt and the now largely eroded Falkland Mountain Range (Catuneanu et al., 2005). The Pre-Cambrian or Lower Palaeozoic crystalline 'Basement' rocks comprising gneiss, granulite and some granite are hence extensive. Down sagging of mountain belt forelands is where much of the younger Karoo (Jurassic) sediments accumulated (Catuneanu et al., 2005). Weatherresistant Karoo alkaline granitic and syenitic intrusions form the elevated south-east uplands (BGS, 2004). Karoo igneous rocks occur locally in Southern Malawi as basaltic intrusions. Thick Karoo sediments (mainly Permo-Triassic), comprising mainly sandstones, marls and conglomerates with some coal seams, occur in the north and south with younger Cretaceous to Pleistocene age sediments locally present. Recent Quaternary alluvium, colluvium and lacustrine deposits occupy the plains; significant alluvium arises from erosion of rift escarpment material (BGS, 2004). Groundwater supplies are mostly hand-pumped from the Quaternary alluvial aquifer that can be high yielding (up to $15 \mathrm{l} / \mathrm{s}$ ), or Basement/bedrock where yields are sensitive to the distribution of overlying colluvium, the degree of weathering and frequency of faults, joints and bedrock fractures (Upton et al., 2016). Yields of $0.51 / \mathrm{s}$, sufficient for hand-pumps, are viable where saturated weathered thicknesses are $>10 \mathrm{~m}$ (Smith-Carington and Chilton, 1983). Some groundwater resources also exist in: Mesozoic alkaline and basaltic intrusions in the south-east uplands that are poorly permeable, but largely freshwater; Karoo sediments, usually well

RIVETT, MO; ROBINSON, HL; WILD, LM; MELVILLE, J; MCGRATH, L; PHIRI, P; FLINK, J; WANANGWA, GJ; MLETA, P; MACLEOD, SSP; MILLER, AVM; KALIN, RM 
cemented with low porosity, but where fractured may allow groundwater flow; and, Cretaceous sediments, where less well-indurated (BGS, 2004).

Review of Malawi literature and archive data: A literature review was undertaken to collate Malawian groundwater arsenic occurrence data. Archive groundwater quality data held by the regulator, the Ministry of Agriculture, Irrigation and Water Development (MoAIWD), were also reviewed, covering electronic databases on groundwater quality collated under various initiatives. The data span 1980 to 2017 and cover the early 1990s onset of growing international awareness of groundwater arsenic. Collation, of these records into a single management information system, however, remains an on-going MoAIWD effort. Additional to these data sets, a nonexhaustive review was made of other known 'ad-hoc' MoAIWD paper records, or third party, for example non-governmental organisation (NGO), reports held.
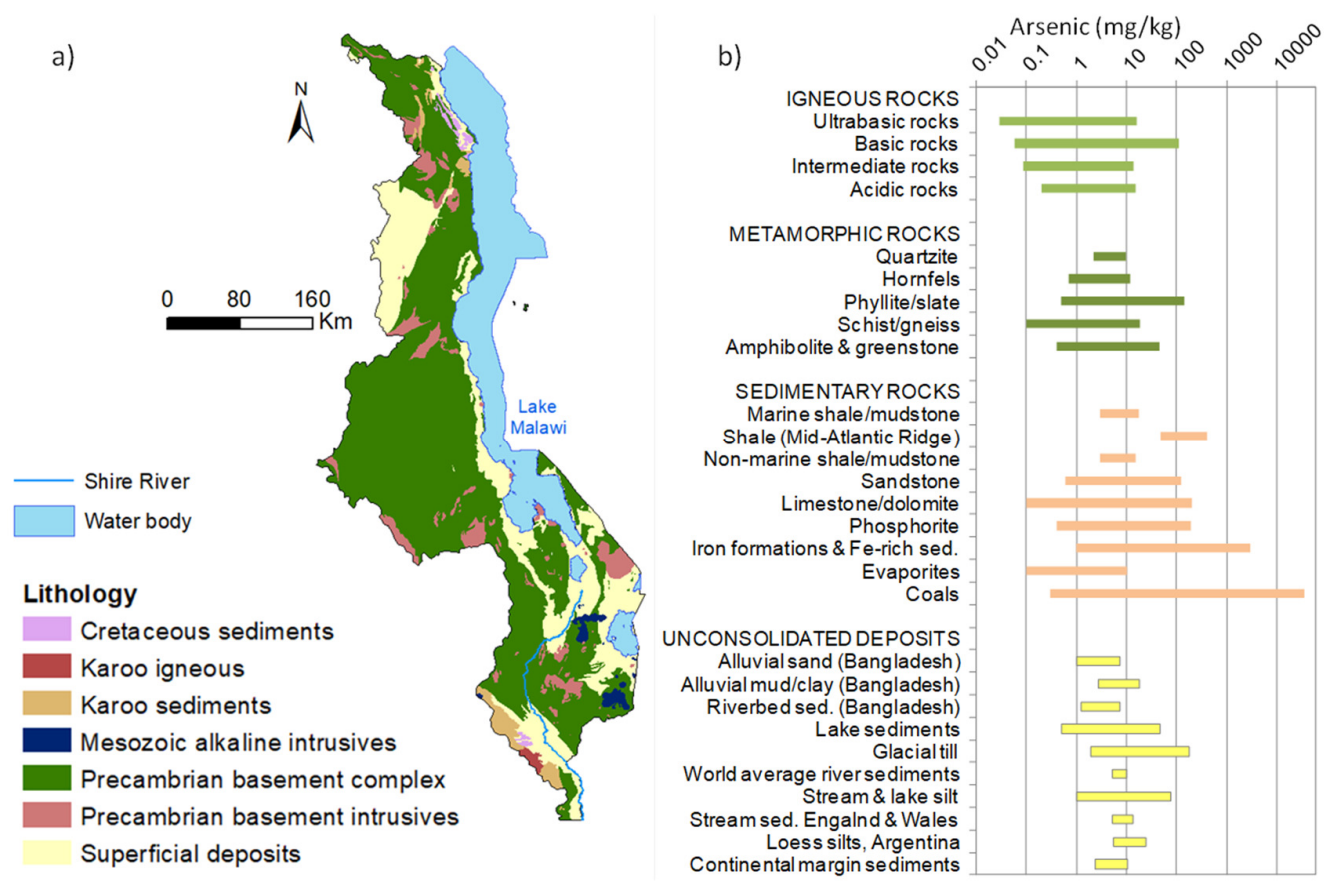

Fig. 1. a) Geology of Malawi; and, b) typical ranges of arsenic in rocks and sediments, based on Smedley and Kinniburgh (2013).

Field surveys - design rationale: Groundwater-quality surveys were conducted in 2014-16 of hand-pumped boreholes widely used for rural community drinkingwater - domestic supply, or by schools and hospitals. Surveys were targeted in possible areas of increased arsenic susceptibility. Although archive groundwater data with sporadically elevated iron in Maseya, Katunga and Ngabu Traditional Authorities (TAs) in Chikwawa District could signify reducing conditions conducive to arsenic release, data paucity precluded such occurrences being that useful in guiding area selection. Anticipated rock arsenic content was considered by comparing to the international tabulation of Smedley and Kinniburgh (2013), summarised in Fig. 1b. For example, biotitehornblende gneisses are unlikely to be greatly impacted by weathering with solid-phase arsenic expected to be low ( $<20 \mathrm{mg} / \mathrm{kg}$, per Fig. 1b). Coal shales in Lengwe National Park could pose high risk (up to $35,000 \mathrm{mg} / \mathrm{kg}$ arsenic in coals, per Fig. 1b), however, boreholes were absent due to Park restrictions. Arsenic contamination may be connected with pyrite presence (data limited) and reduced conditions within igneous rocks such as basalt (up to $113 \mathrm{mg} / \mathrm{kg}$, per Fig. 1b). TA Ngabu was hence selected as an area with higher arsenic risk in that weathering could be high in the Karoo basaltic bedrock. Alluvial deposits there are also partly derived from basalts known to contain elevated iron-bearing magnetite and arsenic within the range of 3-41 mg/kg (Smedley and Kinniburgh, 2002).

Groundwater-quality field surveys: Locations of all sites sampled in our various surveys conducted over 2014-18 are shown in Fig. 2. All surveys were undertaken during June, within the hot-dry season and onset of declining water tables. Surveys in 2014 comprised: 42 boreholes within the basaltic bedrock

RIVETT, MO; ROBINSON, HL; WILD, LM; MELVILLE, J; MCGRATH, L; PHIRI, P; FLINK, J; WANANGWA, GJ; MLETA, P; MACLEOD, SSP; MILLER, AVM; KALIN, RM 
aquifer in TA Ngabu (Wild, 2014); and, 55 boreholes (43 in TA Ngabu, 12 in Kakoma, Mwanza Valley, TA Chapananga) within the Shire River Basin alluvial aquifer (Melville, 2014). In 2015, a higher resolution survey was made of 93 boreholes in the Mwanza Valley alluvial aquifer at Kakoma (McGrath, 2015). In 2016, a re-survey of the TA Ngabu area comprised sampling of 98 additional boreholes in similar areas to the 2014 surveys (Flink, 2016). The 2016 survey also sampled two 'geothermal boreholes' in the Neno District thought to contain, possibly arsenic-rich, geothermal groundwater contributions arising from upward groundwater discharge (via faults etc.) from depth.

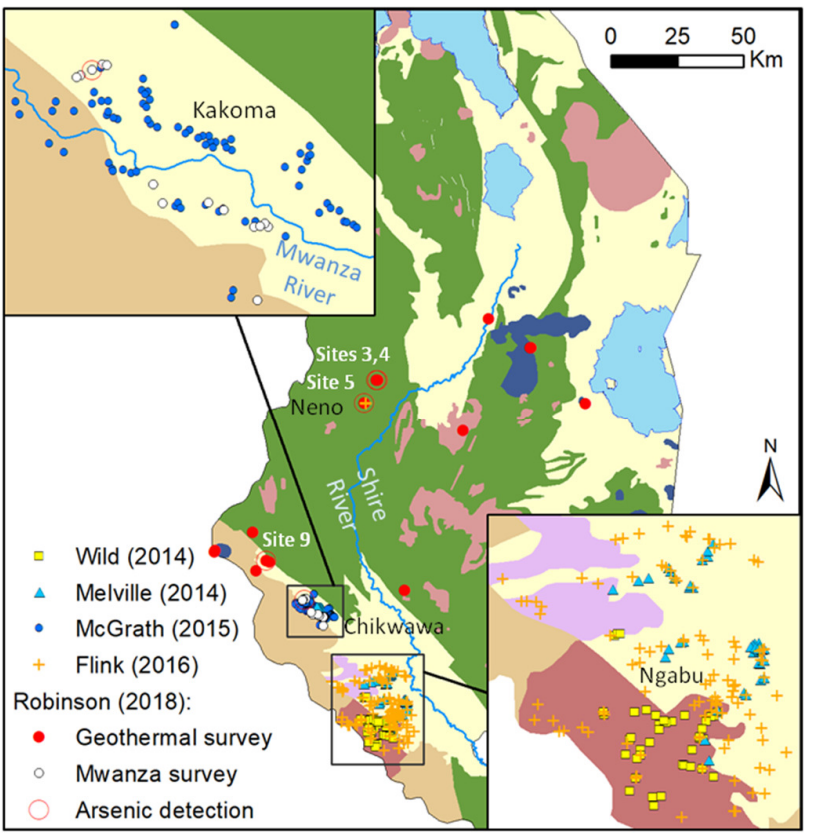

Fig. 2. Borehole locations sampled during surveys of groundwater quality - arsenic occurrence in Southern Malawi during 2014-18 by the CJF programme.

Survey work in 2018 comprised two components (Fig. 2): further examination of arsenic occurrence associated with known or suspected geothermal groundwater discharges at springs or boreholes in Southern Malawi, within the Districts of Blantyre, Chikwawa, Machinga, Ntcheu and Zomba (Robinson, 2018); and, further study of the Mwanza Valley alluvial aquifer, primarily to assess vertical variation in salinity, with arsenic data also being obtained (MacLeod, 2018). The geothermal survey examined 15 sites at 230 to $860 \mathrm{~m}$ ground elevation that were located near faults or geological/intrusion features, comprising 10 springs and 5 boreholes (3 'artesian' naturally flowing boreholes). These comprised 4 sites in the alluvium/colluvium underlain by Karoo sediments, 8 Basement sites, 2 igneous-rock sites, and 1 site in faulted Karoo sediments. The Mwanza Valley study obtained 20 samples, comprising 9 samples from nested (different-depth) piezometer sites at three localities (Manjolo, Kampomo and Chabwedzeka), and the remaining 11 samples from hand-pump supplies in the vicinity.
Chemical analysis: Arsenic for the 2014-16 surveys was screened with the $\mathrm{Hach}^{\circledR}$ EZ Arsenic Test Kit (Hach, 2015). Similar to other kits, it is based upon the Gutzeit method (George et al., 2012). Any sample hydrogen sulphide is oxidised to sulfate. Addition of sulfamic acid and zinc then reduces arsenic to arsine gas that reacts with test-strip mercuric bromide to form arsenic-mercury halogenides (e.g., $\mathrm{AsH}_{2} \mathrm{HgBr}$ ) that yield different strip colour grades depending upon sample amounts of arsenic. Concentration thresholds of $0,10,30,50,100,300,500 \mu \mathrm{g} / \mathrm{l}$ are identified with the colour chart, but concentrations are not determined. George et al. (2012) confirms the $\mathrm{Hach}^{\circledR}$ EZ kit offered high reliability with $97-100 \%$ of waters tested being correctly identified relative to 10 or 50 $\mu \mathrm{g} / 1$ thresholds.

For the 2018 survey, total arsenic was quantified to a detection limit of $3.0 \mu \mathrm{g} / \mathrm{l}$ using Inductively coupled plasma optical emission spectrometry (ICP-OES) analysis on $0.45 \mu \mathrm{m}$ filtered samples preserved at site (20\% nitric acid) and shipped for analysis to the Univ. of Strathclyde laboratory, Scotland (Robinson, 2018).

RIVETT, MO; ROBINSON, HL; WILD, LM; MELVILlE, J; MCGRATH, L; PHIRI, P; FLINK, J; WANANGWA, GJ; MLETA, P; MACLEOD, SSP; MILLER, AVM; KALIN, RM 
Supporting data for major ions, iron, $\mathrm{pH}$, electrical conductivity (EC), total dissolved solids (TDS) and temperature were obtained using field probes or wetchemistry methods (Rivett et al., 2018; Robinson 2018) using MoAIWD laboratories for all 2014-16 survey samples; and, for the 2018 survey, modern (IC, ICP-OES) methods on shipped samples.

\section{RESULTS AND DISCUSSION}

Review of literature studies: Data from known Malawian surveys by other authors reporting arsenic in groundwater are summarised in Fig. 3. Two of the three surveys reported arsenic data in passing. The earliest published case appears to be Pritchard et al.
(2007, 2008) and Mkandawire (2008) who undertook dry-season (August and October 2006) and wet-season (February and April 2007) surveys of 52 hand-dug shallow $(<15 \mathrm{~m}$ deep) wide-diameter $(>1 \mathrm{~m})$ wells across six districts in Southern Malawi (Fig. 3). Their rationale was to examine supplies vulnerable to anthropogenic contamination. Gross microbiological contamination proved to be particularly apparent in the wet season. Arsenic analysis was undertaken in Malawi via wet-chemistry - photometer analysis, or the Rapid arsenic test kit (Quick Econo II). For all 225 samples tested, arsenic was reported below the 2-3 $\mu \mathrm{g} / 1$ detection limit applicable. Reporting did not comment upon factors controlling arsenic absence.

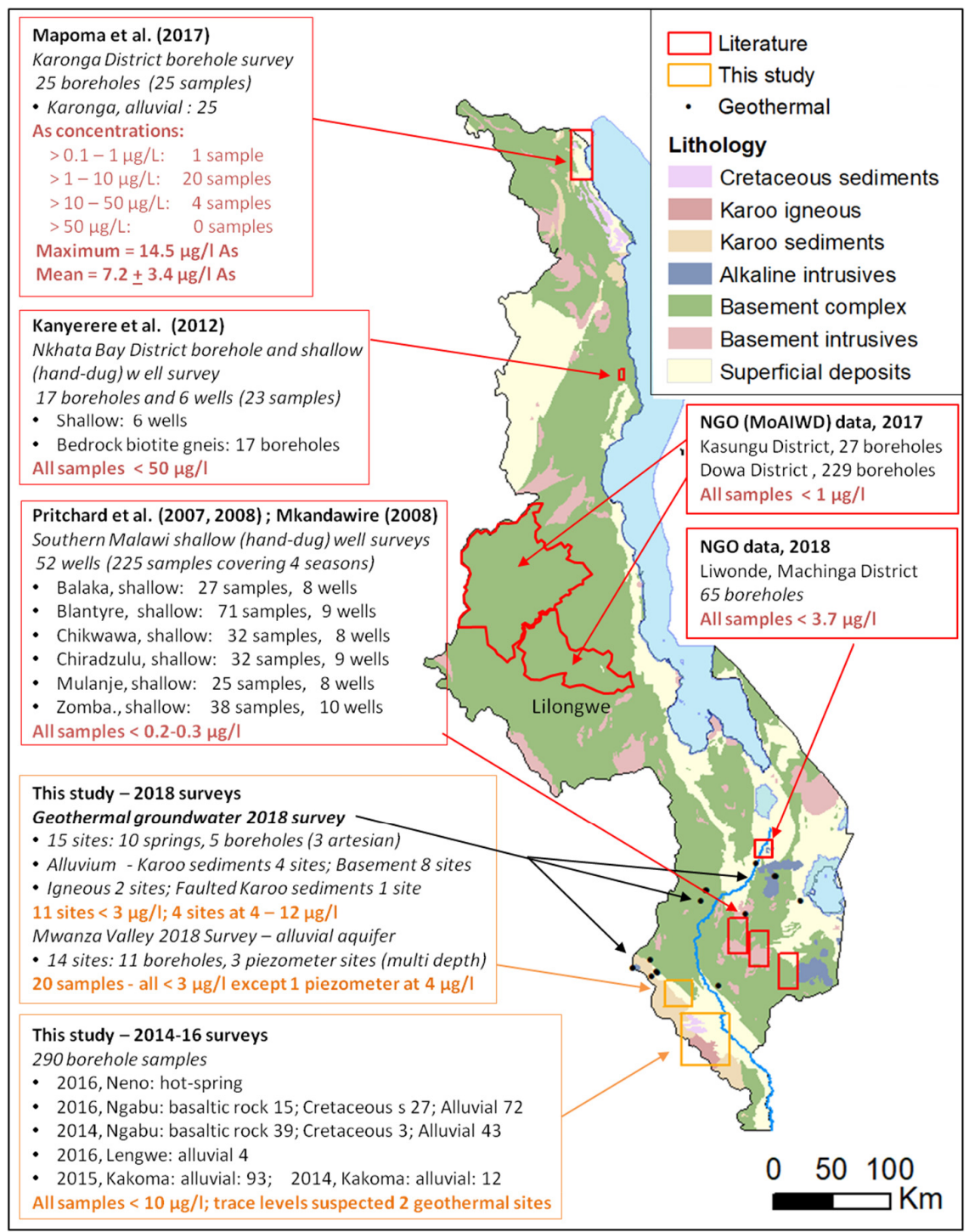

Fig. 3. Summary of arsenic occurrence in Malawian groundwater based on review of literature archive studies and our 2014-18 surveys.

RIVETT, MO; ROBINSON, HL; WILD, LM; MELVILlE, J; MCGRATH, L; PHIRI, P; FLINK, J; WANANGWA, GJ; MLETA, P; MACLEOD, SSP; MILLER, AVM; KALIN, RM 
The study by Kanyerere et al. (2012) likewise focused upon microbiological risks. The authors surveyed 17 boreholes in bedrock biotite gneiss units and 6 (handdug) shallow wells in the rural Nkhata Bay District, Northern Malawi. Arsenic for all samples was below Malawi's Maximum Permissible Limit of $50 \mu \mathrm{g} / \mathrm{l}$ (Malawi Standards, 2005). Further comments on arsenic were not made. Analysis was via ICP-OES in South Africa; as such, detection limits were potentially in the low $\mu \mathrm{g} / \mathrm{l}$ range, however, quantified concentration data below $50 \mu \mathrm{g} / \mathrm{l}$ were not reported. Mapoma et al. (2017) present a 2015 survey of groundwater-quality constraints upon drinking-water and irrigation use (for rice growing), sampling 25 boreholes of 35-60 m depth in the Karonga District alluvial plain aquifer that borders northern Lake Malawi. Arsenic analysis was conducted in China using ICP-OES. Most boreholes tested were in the 1$10 \mu \mathrm{g} / \mathrm{l}$ range, with four just exceeding the WHO 10 $\mu \mathrm{g} / \mathrm{l}$ drinking-water guideline, up to $14.5 \mu \mathrm{g} / \mathrm{l}$. The arsenic mean of $7.2 \pm 3.4 \mu \mathrm{g} / \mathrm{l}$ is indicative though of concentrations frequently approaching the WHO drinking-water guideline. Mapoma et al. (2017) emphasise the need for follow-up investigations in the district to clarify that the situation is not hazardous to human health, noting elevated arsenic is synonymous with hard water and high fluoride occurrence. Increased arsenic also correlates with more reducing conditions, although not that reducing compared to globally significant arsenic cases. They suggested that arsenic is perhaps mobilized by changes in groundwater redox coupled to fluid-rock interactions and $\mathrm{pH}$ change leading to dissolution of Arsenicbearing minerals. They conducted some geochemical (PHREEQC) modelling substantiating this possibility. The study represents Malawi's most detailed consideration of hydrochemical controls upon local arsenic occurrence.

Ministry (MoAIWD) archive data: The MoAIWD laboratory does not include arsenic analysis within its current routine groundwater quality monitoring suite of 20-23 parameters, nor within any suites used previously (MoAIWD, 2017). Much of this analysis is conducted at the request of clients, mainly NGOs assessing (new) water-point quality. Inspection of the electronic archive groundwater quality concentration data within all available databases collated from 1980 to 2017 failed to reveal any arsenic concentration data. Detailed in MoAIWD (2017), and commented upon in Rivett et al. (2019), the MoAIWD's laboratories require significant investment. Whilst wet-chemistryphotometry methods or test kit methods for arsenic could be implemented, reagent kit costs largely prevent their routine use (in the absence of obvious health concerns). Although an atomic absorption spectrophotometry (AAS) instrument is housed by the laboratory in Blantyre, and capable of low $\mu \mathrm{g} / \mathrm{l}$ arsenic detection, the near obsolete instrument is reported as faulty and not used (MoAIWD, 2017). Facility investment is, however, being made with the recent acquisition of an AAS for the headquarter Central Water Laboratory and an ICP-OES (or MS) is proposed within the National Water Resources Master Plan (MoAIWD, 2017).

A trawl of data held by the MoAIWD arising from third-party (e.g., NGO) activity found two datasets. An NGO's dataset from a 2016-17 survey revealed below detection limit, $<1 \mu \mathrm{g} / \mathrm{l}$, arsenic for all 229 borehole samples taken from the Dowa District, with similar results for 27 borehole samples from the Kasungu District, both located north of Lilongwe in Basement rock (Fig. 3). Significantly, arsenic analysis was a condition imposed upon the NGOs by their funders to ensure water delivered from installed water points was safe for human consumption. The MoAIWD laboratory undertook analysis for most determinants, but out-sourced arsenic analysis via AAS to the ARET (Agricultural Research and Extension Trust) laboratory in Malawi. A second dataset held by the MoAIWD from a different NGO contained results from sampling in 2018 of 65 boreholes around Liwonde in Machinga District (Fig. 3). The area is close to the Shire River and overlies alluvial or Basement rock units. Analysis was via AAS with all samples below the $<3.7 \mu \mathrm{g} / \mathrm{l}$ detection limit.

Potentially some further arsenic data could exist. Mapoma and Xie (2014) comment "Arsenic is not a problem currently based on spot checks carried out by the ministry"; however, these data were not found in the MoAIWD archive collated. It is possible that further unpublished data may be held by NGOs, or perhaps other visiting international research bodies and/or their collaborating universities in Malawi.

2014-18 Survey Results: Our survey results for 201416 and 2018 are summarised in Fig. 3. Sample-point locations exhibiting detectable arsenic are circled in Fig. 2. None of the 2014 surveys covering the TA Ngabu basaltic bedrock, the alluvial aquifer to the immediate east and Kakoma - Mwanza Valley exhibited detectable concentrations of arsenic registering 'zero' concentration using the test kit. It was concluded arsenic throughout was below the kit minimum $10 \mu \mathrm{g} / \mathrm{l}$ positive detection threshold. Similar, below detection, results were obtained for the more spatially intensive survey of the Kakoma alluvial aquifer in 2015. The 2016 re-survey of the TA Ngabu basaltic bedrock and alluvial aquifer systems also reconfirmed below $10 \mu \mathrm{g} / \mathrm{l}$ detection threshold

RIVETT, MO; ROBINSON, HL; WILD, LM; MELVILlE, J; MCGRATH, L; PHIRI, P; FLINK, J; WANANGWA, GJ; MLETA, P; MACLEOD, SSP; MILLER, AVM; KALIN, RM 
concentrations across these areas. Quantified arsenic concentrations in the Mwanza Valley survey in 2018 near Kakoma were all below $3 \mu \mathrm{g} / \mathrm{l}$ with the exception of one piezometer sample at $4 \mu \mathrm{g} / \mathrm{l}$. It was therefore concluded arsenic throughout the sampled regions of these aquifer was consistently below the WHO drinking-water guideline of $10 \mu \mathrm{g} / \mathrm{l}$, and comfortably within the Malawi drinking-water Standard of $50 \mu \mathrm{g} / \mathrm{l}$. These results were observed despite our targeting of geological systems in Southern Malawi thought to be at higher risk of arsenic contamination based on rocktype characteristics. It remains unclear if the low arsenic relates to an absence of hydrochemical solution (groundwater) conditions favouring arsenic release from sediments, or an absence of potentially available arsenic within the aquifer sediment itself, or both. Our supporting hydrochemical data endorse conceptualisation of a typical alluvial valley escarpment bedrock/Basement system (Rivett et al., 2018, 2019). This comprises a lower TDS recent recharge $\mathrm{Ca} / \mathrm{Mg}-\mathrm{HCO}_{3}$ type groundwater in shallow fractured escarpment and valley margin alluvial units developing to medium TDS, ion-exchange influenced, $\mathrm{Na}-\mathrm{HCO}_{3}$ groundwater mid-plain, to highest TDS, potentially brackish, $\mathrm{Na}-\mathrm{Cl}$ (SO4) groundwater towards groundwater discharge areas around the Shire River lowlands. The lack of quantified arsenic concentrations in the $0.1-10 \mu \mathrm{g} / \mathrm{l}$ range and adequate definition of reducing (redox) conditions limits analysis of controls upon the expected heterogeneous occurrence of low $(<10 \mu \mathrm{g} / \mathrm{l})$ arsenic concentrations and correlations with arsenic presence (as developed by Mapoma et al. (2017) for Karonga District, per above). Partial insight though was achieved by using iron data to infer redox conditions, and with observed $\mathrm{pH}$, assess potential arsenic mobilisation. Preliminary geochemical modelling with reference to arsenic (and iron) $\mathrm{pH}-\mathrm{E}_{\mathrm{H}}$ phase diagrams and use of the 2014 basaltic rock survey groundwater $\mathrm{pH}$ (6.02-8.11 range, mean $6.93 \pm 0.47)$ and total iron $(0.05-0.8 \mathrm{mg} / \mathrm{l}$, mean $0.20 \pm 0.17 \mathrm{mg} / \mathrm{l})$ and 2014 alluvial survey $\mathrm{pH}(6.37$ 8.02 , mean $7.20 \pm 0.43)$ and total iron $(0.02-0.77 \mathrm{mg} / \mathrm{l}$, mean $0.30 \pm 0.18$ ) data (Melville, 2014; Wild, 2014), soluble arsenic species were predicted over the range of groundwater conditions sampled. This may infer a lack of arsenic-bearing minerals could account for the observed low arsenic.

Geothermal groundwater survey results: Test kit analysis of both boreholes surveyed in 2016 in Neno District (Fig. 2) containing geothermal groundwater, although below the first increment of positive detection of $10 \mu \mathrm{g} / \mathrm{l}$, registered faint colouration above the typical 'zero' colour. Observed temperatures of $39^{\circ} \mathrm{C}$ and $50^{\circ} \mathrm{C}$ confirmed significant geothermal groundwater contributions.
The 2018 geothermal survey found 11 sites below the $3 \mu \mathrm{g} / \mathrm{l}$ detection limit, but with four sites detecting arsenic (Fig. 2). The Site 9 borehole (July Village) recorded $4 \mu \mathrm{g} / \mathrm{l}$ within the alluvium/colluvium underlain by Karoo sediments adjacent to the exposed Basement lithology of the Mwanza Fault footwall; Site 5 borehole (Mapundi Village) exhibited $9 \mu \mathrm{g} / \mathrm{l}$ within colluvium underlain by Basement with proximal faulting (intrusions absent); and, spring Sites 4 and 3 at $10 \mu \mathrm{g} / \mathrm{l}$ and $12 \mu \mathrm{g} / \mathrm{l}$ respectively, located $400 \mathrm{~m}$ apart at Manondo Village. The springs discharge from PreCambrian Basement hornblende-biotite gneiss (with epidote) and are located along an E-W trending fault connected to a network of smaller faults and a nearby phonolite intrusion (Robinson, 2018). Both borehole sites are used for drinking-water - domestic supply and both springs for bathing and domestic activities (Robinson, 2018). Whilst solid-phase arsenic is expected to be low in the biotite-hornblende gneiss (Fig. 1), this lithology is common to these sites, hosting Site 3 and Site 4, underlying Site 5 beneath colluviums, and adjacent to Site 9. Despite the modest concentrations, a plot of arsenic versus groundwater temperature (Fig. 4a) confirms detectable arsenic was found in the warmest boreholes (both $49^{\circ} \mathrm{C}$ ) and springs $\left(38^{\circ} \mathrm{C}\right.$ and $\left.41^{\circ} \mathrm{C}\right)$ and corroborates the significance of geothermal waters to arsenic occurrence in supplies. Several chemical parameters further endorse the importance of geothermal contributions by similarly exhibiting increased concentrations with sampled groundwater temperature. For instance, increased lithium with temperature (Fig. 4b) may be ascribed to its frequent occurrence in geothermal waters (Rowland et al., 2011) and deep subsurface brines with elevated lithium (albeit tightly bound) found within granitic rocks. Lithium concentrations significantly exceeded the mean of $23 \pm 2 \mu \mathrm{g} / \mathrm{l}$ found in Irish shallow-granite groundwater (Kavanagh et al., 2017). Increased fluoride with temperature (Fig. 4c) is likewise attributed to hydrothermal sources, common in the EARS. Malawian groundwaters in the eastern alluvial plain rift zone and Central Malawi Basement are likely to be most influenced by fluoride (BGS, 2004). Fluoride poses the most significant health risk of the parameters analysed, with concentrations approaching $10 \mathrm{mg} / \mathrm{l}$, and $73 \%$ of samples above the WHO $1.5 \mathrm{mg} / \mathrm{l}$ drinking-water guideline. Sodium, considering multiple source and ion exchange influences possible, exhibits a particularly linear increase with temperature that could be attributed to the influence of deep geothermal brines (Fig. 4d). Arsenic in geothermal waters may arise from fluid-rock interactions of arsenic-bearing minerals such as pyrite in the thermal reservoir, or by migrating hot fluid scavenging of

RIVETT, MO; ROBINSON, HL; WILD, LM; MELVILlE, J; MCGRATH, L; PHIRI, P; FLINK, J; WANANGWA, GJ; MLETA, P; MACLEOD, SSP; MILLER, AVM; KALIN, RM 
arsenic from overlying aquifer rocks (Rowland et al., 2011). The relative importance of these processes controlling arsenic occurrence and the hydrochemistry and energy resource value of geothermal groundwaters are the subject of on-going work that is supported by stable isotope facilities recently developed in Malawi (Robinson, 2018).
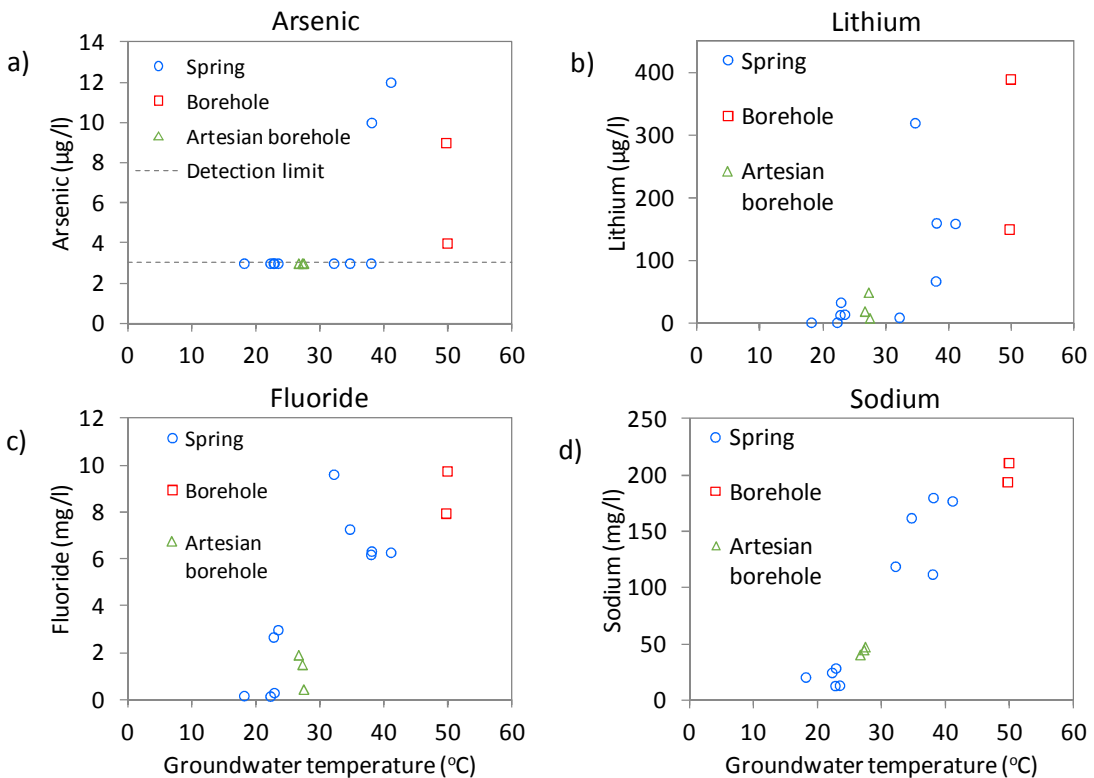

Fig. 4. Geothermal groundwater 2018 survey: plots of groundwater temperature versus: a) arsenic, b) lithium, c) fluoride, and d) sodium.

In summary, the geothermal survey data reinforce the significance of geothermal water components controlling observed water quality and arsenic occurrence. Arsenic concentrations detected in the geothermal groundwaters are the highest found in our surveys, but remain modest at $<15 \mu \mathrm{g} / \mathrm{l}$, and comparable to the archive Malawian literature survey maximum (Fig. 3). Hence, although maxima just exceed the WHO $10 \mu \mathrm{g} / \mathrm{l}$ drinking-water guideline and are thus somewhat troublesome, arsenic concentrations observed to date throughout Malawi still remain comfortably within the $50 \mu \mathrm{g} / \mathrm{l}$ limit applied for water delivered from boreholes and protected shallow wells (Malawi Standards, 2005). The findings overall affirm earlier expectations for the Malawian (hydro) geological circumstance that arsenic concentrations in groundwater may be generally low (BGS, 2004). The troublesome breaches of the current WHO drinking-water guideline though still point to the need for further investigations of areas prone to geothermal groundwater contributions and, or reducing conditions, especially in alluvial aquifer systems with natural or anthropogenic sources of organic matter. In total, 919 groundwater samples (Fig. 3 total) have been subjected to arsenic analysis, representing testing of just $1 \%$ of water points projected to now exist across Malawi. Hence there remains significant work to be done in the further assurance of water supply quality. Given that arsenic concentrations detected to date are mainly in the $1-20$ $\mu \mathrm{g} / \mathrm{l}$ range, there is a parallel need for Malawi (the MoAIWD) to develop modern laboratory facilities and capacity to routinely determine concentrations within this range and possible variation in population exposures to groundwater arsenic.

Conclusions: Our surveys and sparse literature confirm arsenic in Malawian groundwater appears low, and well within the national $50 \mu \mathrm{g} / \mathrm{l}$ standard applied. Most groundwater supplies were below the 10 $\mu \mathrm{g} / \mathrm{l}$ WHO drinking-water guideline, with marginal breaching in one alluvial-aquifer literature survey, and our survey samples containing geothermal groundwater contributions. Further research is needed to confirm human-health risks are low; including, increased monitoring of the great many hand-pumped supplies, and assessing hydro-biogeochemical controls on the higher arsenic concentrations found.

Acknowledgements: The authors gratefully acknowledge the funding of this research by the Scottish Government under the Scottish Government Climate Justice Fund Water Futures Programme research grant HN-CJF-03 awarded to the University of Strathclyde (R.M. Kalin).

RIVETT, MO; ROBINSON, HL; WILD, LM; MELVILLE，J; MCGRATH，L; PHIRI，P; FLINK，J; WANANGWA, GJ; MLETA, P; MACLEOD, SSP; MILLER, AVM; KALIN, RM 


\section{REFERENCES}

Ahmed, KM; Bhattacharya, P; Hasan, MA; Akhter, SH; Alam, SM; Bhuyian, MA; Imam, MB; Khan, AA; Sracek, O (2004). Arsenic enrichment in groundwater of the alluvial aquifers in Bangladesh: an overview. Appl. Geochem. 19: 181-200.

https://doi.org/10.1016/j.apgeochem.2003.09.006

Ahoulé, DG; Lalanne, F; Mendret, J; Brosillon, S; Maïga, AH (2015). Arsenic in African waters: a review. Water Air Soil Pollut. 226: 302. https://doi.org/10.1007/s11270-015-2558-4

BGS (British Geological Survey) (2004). Groundwater quality: Malawi. BGS - WaterAid country information sheet.

https://www.bgs.ac.uk/downloads/start.cfm?id=1283

Catuneanu, O; Wopfner, H; Eriksson, P; Cairncross, B; Rubidge, B; Smith, R; Hancox, P (2005). The Karoo basins of south-central Africa. J Afr. Earth Sci. 43: 211-253.

https://doi.org/10.1016/j.jafrearsci.2005.07.007

Flink, J (2016). Evaluation of areas at risk of arsenic contamination in Malawi and the risk of arsenic contamination in hotspring boreholes. MSc Hydrogeology thesis (unpublished), Dept. Civil \& Environmental Engineering, University of Strathclyde.

George, CM; Zheng, Y; Graziano, JH; Rasul, SB; Hossain, Z; Mey, JL; Van Geen, A (2012). Evaluation of an arsenic test kit for rapid well screening in Bangladesh. Environ. Sci. Technol. 46(20): 11213-11219.

http://dx.doi.org/10.1021/es300253p

Hach (2015) EZ arsenic high range test kit. http://www.hach.com/ezarsenic-high-range-testkit/product?id=7640217305

Hoque, MA; Burgess, WG; Ahmed, KM (2017). Integration of aquifer geology, groundwater flow and arsenic distribution in deltaic aquifers-A unifying concept. Hydrol. Proc. 31(11): 20952109.

https://doi.org/10.1002/hyp.11181

Kanyerere, T; Levy, J; Xu, Y; Saka, J (2012). Assessment of microbial contamination of groundwater in upper Limphasa River catchment, located in a rural area of northern Malawi. Water SA 38(4): 581-596. http://hdl.handle.net/10566/710
Kavanagh, L; Keohane, J; Cleary, J; Cabellos, GG; Lloyd, A (2017). Lithium in the natural waters of the South East of Ireland. Int. J. Environ. Res. Public Health 14: 561.

http://dx.doi.org/10.3390/ijerph14060561

MacLeod, S (2018). Vertical chracateristics of a saline-contaminated aquifer in the Mwanza valley, Southern Malawi. MSc Hydrogeology thesis (unpublished), Dept. Civil \& Environmental Engineering, University of Strathclyde.

Mapoma, HWT; Xie, X (2014). Basement and alluvial aquifers of Malawi: An overview of groundwater quality and policies. Afr. J. Environ. Sci. Technol. 8(3): 190-202.

http://dx.doi.org/10.5897/AJEST2013.1639

Mapoma, HWT; Xie, X; Liu, Y; Zhu, Y; Kawaye, FP; Kayira, TM (2017). Hydrochemistry and quality of groundwater in alluvial aquifer of Karonga, Malawi. Environ. Earth Sci. 76: 335. https://doi.org/10.1007/s12665-017-6653-2

McGrath, L (2015). Potential for arsenic contamination of the groundwater in the Kakoma Health District within the Traditional Authority of Chapananga, Chikwawa, Malawi. MSc Hydrogeology thesis (unpublished), Department of Civil and Environmental Engineering, University of Strathclyde.

Melville, J (2014). Groundwater quality and arsenic contamination in the alluvial deposits of the Chikwawa district, Malawi. MSc Hydrogeology thesis (unpublished), Department of Civil and Environmental Engineering, University of Strathclyde.

Mkandawire, T (2008). Quality of groundwater from shallow wells of selected villages in Blantyre District, Malawi. Phys. Chem. Earth. 33: 807811.

https://doi.org/10.1016/j.pce.2008.06.023

MoAIWD (Ministry of Agriculture, Irrigation and Water Development) 2017. National Water Resources Master Plan, Annex 3 - Water quality. Lilongwe, Malawi.

Malawi Standards (2005). Malawi Standard MS 733:2005 Borehole and Protected Shallow well water quality specification.

RIVETT, MO; ROBINSON, HL; WILD，LM; MELVILLE，J; MCGRATH， L; PHIRI，P; FLINK，J; WANANGWA, GJ; MLETA, P; MACLEOD, SSP; MILLER, AVM; KALIN, RM 
Pritchard, M; Mkandawire, T; O’Neil, JG (2007). Biological, chemical and physical drinking water quality from shallow wells in Malawi: Case study of Blantyre, Chiradzulu and Mulanje. Phys. Chem. Earth 27: 845-850.

https://doi.org/10.1016/j.pce.2007.07.013

Pritchard, M; Mkandawire, T; O'Neill, JG (2008). Assessment of groundwater quality in shallow wells within the southern districts of Malawi. Phys. Chem. Earth, B: Hydrol. Oceans Atmos. 33(8-13): http://dx.doi.org/10.1016/j.pce.2008.06.036

Ravenscroft, P; Brammer, H; Richards, K (2009). Arsenic Pollution: A global synthesis. Wiley Blackwell. 617pp.

Rivett, MO; Budimir, L; Mannix, N; Miller, AVM; Addison, MJ; Moyo, P; Wanangwa, GJ; Phiri, OL; Songola, CE; Nhlema, M; Thomas, MAS; Polmanteer, RT; Borge, A; Kalin, RM (2019). Responding to salinity in a rural African alluvial valley aquifer system: to boldly go beyond the world of hand-pumped groundwater supply? Sci. Total Environ. 653: 1005-1024.

https://doi.org/10.1016/j.scitotenv.2018.10.337

Rivett, MO; Miller, AVM; MacAllister, DJ; Fallas, A; Wanangwa, GJ; Mleta, P; Phiri, P; Mannix, N; Monjerezi, M; Kalin, RM (2018). A conceptual model based framework for pragmatic groundwater-quality monitoring network design in the developing world: Application to the Chikwawa District, Malawi. Groundwater for Sustainable Development 6: 213-226. https://doi.org/10.1016/j.gsd.2018.01.005

Robinson, H (2018). A hydrogeochemical assessment of the geothermal potential of Southern Malawi. MSc Hydrogeology thesis (unpublished), Department of Civil and Environmental Engineering, University of Strathclyde.

Rowland, HAL; Omoregie, EO; Millot, R; Jimenez, C; Mertens, J; Baciu, C; Hug, SJ; Berg, M (2011). Geochemistry and arsenic behaviour in groundwater resources of the Pannonian Basin (Hungary and Romania). Appl. Geochem. 26: 117.

https://doi.org/10.1016/j.apgeochem.2010.10.006

Smedley, PL; Kinniburgh, DG (2002). A review of the source, behaviour and distribution of arsenic in natural waters. Appl. Geochem. 17: 517- 568.

http://dx.doi.org/10.1016/S0883-2927(02)00018-5

Smedley, PL; Kinniburgh, DG (2013). Arsenic in Groundwater and the Environment. In: Essentials of Medical Geology, Revised Edition, Springer, New York.

Smith-Carington, AK; Chilton, PJ (1983). Groundwater Resources of Malawi. Overseas Development Administration Institute of Geological Sciences. http://resources.bgs.ac.uk/sadcreports/malawi198 3smithcarringtonmalawigwresources.pdf

Upton, K; Ó Dochartaigh, BÉ; Chunga, B (2016). Africa Groundwater Atlas: Hydrogeology of Malawi. British Geological Survey.

http://earthwise.bgs.ac.uk/index.php/Hydrogeology_o f_Malawi

WHO (2011). WHO Guidelines for drinking-water quality, fourth edition.

http://www.who.int/water_sanitation_health/publicati ons/2011/dwq_gui delines/en/

WHO and UNICEF (World Health Organization and the United Nations Children's Fund) (2017). Progress on drinking water, sanitation and hygiene: 2017 update and SDG baselines.

https://www.who.int/water_sanitation_health/publicat ions/jmp-2017/en/

Wild, LM (2014). Groundwater quality and potential arsenic contamination from a geochemical perspective to bedrock geology in the Chikwawa district, Malawi. MSc Hydrogeology thesis (unpublished), Department of Civil and Environmental Engineering, University of Strathclyde.

RIVETT, MO; ROBINSON, HL; WILD, LM; MELVILlE, J; MCGRATH, L; PHIRI, P; FLINK, J; WANANGWA, GJ; MLETA, P; MACLEOD, SSP; MILLER, AVM; KALIN, RM 